“iş, Güç” Endüstri İlişkileri ve İnsan Kaynakları Dergisi

Cilt:9 Sayı:3, Temmuz 2007, ISSN: 1303-2860

“IŞ, Güç" The Journal of Industrial Relations and Human Resources

Vol:9 No:3 July 2007, ISSN: 1303-2860

\title{
MULTICULTURALISM IN AUSTRALIA
}

\author{
ALPER BABACAN \\ Post Doctoral Fellow, RMIT University, Melbourne, Australia
}

\begin{abstract}
PROF. DR. HURRIYET BABACAN
Professor of Social and Cultural Development, Victoria University of

Technology, Melbourne, Australia
\end{abstract}

\begin{abstract}
This article provides an overview of the policy of multiculturalism in Australia. In its early phase, Multiculturalism was a tool for Australia's post-war construction needs as it allowed for governments to manage ethnic diversity. During the 1980s and 1990s, multicultural policies incorporated elements of the economic rationalist agenda and failed to tackle deep seated racism in Australia. Throughout the late 1990s and into the post 2000 period, neo- liberal agendas have dominated the Commonwealth government's policies with Multiculturalism being weakened. Driven by the politics of exclusion, the Howard government's policies have revived the 'new racism' in Australia. His article will first discuss the policy of Multiculturalism in its various phases. Following this, commentary is provided on Multicultural policies. It is concluded that a more inclusive multiculturalism needs to be adopted.
\end{abstract}

Keywords: Multiculturalism, Australia, Racism 


\section{'Old racism and multiculturalism in Australia}

Until the 1970s, colonialism and institutional racism dominated the international climate the international climate. The 'old form of racism' in which ethnic minorities were seen as inferior dominated the cultural landscape (Stokes: 1997, McMaster: 2001). The legal fiction of 'terra nullius' or 'empty land' was engaged by the settlers arriving from England to settle the land on the basis that the Aboriginal people were not cultivating it. This claim was invalidated only after a landmark High Court Case in 1992 (Mabo v Queensland [No2] 1992175 CLR1).

The Immigration Restriction Act 1901 (Cth) (Also called the 'White Australia' policy) lasted until the early 1970s (Larbaleister: 1999). The aim of this Act was to keep out Asian immigrants through a dictation test administered in any European language to any would be Asian immigrant. The policy was motivated by Australia's deep seated fear of being 'invaded' by Asians ('the Yellow Peril') who were intent upon 'threatening' and 'polluting' Australia's 'superior' white race (Dunn et.al.: 2004). This reasoning was used to promote an Australian 'national identity' and 'way of life'.

\section{The Politics of managing ethnic diversity}

After World War II, Australia was unable to recruit adequate numbers of immigrants from Great Britain, its traditional source country, and under the slogan of 'populate or perish' (Hollinsworth: 1999), turned to refugees and immigrants from Europe (McMaster: 2001). By 1965, attracting British migrants had become even more difficult, with many returning to Britain. Australia's geographic isolation and its dominant trading links with Britain and the United States had, until this period, allowed Australia to maintain a racialist border control policy. Australia's relationship with Britain was challenged by Britain's entry into the European Community and its declining influence over Commonwealth countries. At the same time, Australia became increasingly aligned to the United States in political and military terms (Hollinsworth:1999). The Australian economy also started to become integrated into the Asian region by the late 1960s and as a result, the White Australia Policy became difficult to sustain (McMaster 2001:47). Its abolition was essential to improving foreign relations with Australia's Asian neighbours. 
The abandonment of the White Australia Policy in the early 1970s opened the way for public debate on issues of diversity and how to respond to diversity. The solution was seen in adopting multiculturalism as a policy. Multiculturalism as a public policy is a relatively new concept (Jupp et.al. 2001). It was first introduced in Canada in 1971 as a government policy and later adopted as a public policy in Australia by the Whitlam Labour Government in 1973 for 'managing diversity'. Jupp defines multiculturalism as "the public acceptance of immigrants and minority communities as distinct communities, which are distinguishable from the majority population with regard to their language, culture and social behaviour and which have their own associations and social infrastructure" (Jupp et.al. 2001:807). Thus, multicultural policies were seen to represent a departure from the doctrine of assimilation, in which ethnic minorities were expected to give up their distinctive linguistic, cultural and social characteristics and become indistinguishable from the majority of the population (Zubryzcki 1982).

Multicultural policy can be described to have evolved in three phases. The first phase commenced with the election of the Whitlam Labor Government in 1970, with the adoption of cultural pluralism as a basis of social democratic society. Within this framework, migrants were no longer to be seen as aliens but as citizens. Al Grasby, the Minister for Immigration and Ethnic Affairs, in his famous speech on the 'family of nations' paved the way for incorporating cultural diversity and difference into the building of an Australian identity (Jamrozik et.al.1995). The policy developed in this phase enabled ethnic groups to assert their identity and yet at the same time be able to co-exist with a sense of Australian identity. The policy focused on life chances of migrants and was concerned with equality of opportunity within society. For this reasons it has been coined egalitarian multiculturalism (Jayasuriya 2003). In this phase of multicultural policy, the essential Anglo institutional frameworks remained unaltered. Migrants were accepted as citizens and given rights that were conditional upon accepting the common structures of society (the basic legal and political institutions, administrative systems and rule of law) and with English as the official language. These requirements have remained unaltered over time in the evolution of multicultural policy in Australia.

The first phase of multiculturalism came to an end with the election of the conservative Fraser Government (1983). In this new phase, referred to as liberal multiculturalism, The Galbally Report (1978) set the scene for more comprehensive funding for ethnic communities and for migrant settlement. The four principles adopted by Galbally were: equality of 
opportunity; right to maintain and express one's own culture; ethnospecific services; self-help or voluntarism for migrants (Jamrozik et.al. 1995, Jayasuriya 1997). Four principles of Australian multiculturalism adopted were: social cohesion, cultural identity, equal opportunity and access and equal responsibility for participation in society. These principles have remained the core elements of multicultural policy to this date, with minor changes both at the Commonwealth and State Government levels.

In essence, multiculturalism during this early phase recognised the ethnicity, culture, religion and language of Non English Speaking Background (NESB) immigrants whose voting power and contribution to Australia was becoming very significant (Freeman and Jupp: 1992). The policy also officially ended the belief that other races and cultures were inferior. After the inception of multiculturalism, a whole range of services were funded to assist immigrants with their settlement process, including the provision of language services for newly arrived immigrants.

The election of the Hawke-Keating Labor Government (1983-1996) brought in additional notions of social justice to the multicultural mosaic. As a party reputed to stand up for and to be of the working class, Australian Labor Party had connections with many working class immigrants. Thus, there was a strong attempt by the Commonwealth Government to move away from equality of opportunity towards equality in treatment and fairness. Also, the era of this labour government was characterised by deregulation, opening of financial markets, attempts at efficient use of human resources and the attempt to incorporate Australia more clearly within the Asia-Pacific region. In addition, there was a major shift towards accepting into Australia more skilled immigrants with high levels of qualifications. This meant that there was considerable more diversity in terms of both ethnicity and class of immigrants entering Australia. An important policy initiative was the launch of The National Agenda for Multicultural Australia in 1988 by the Prime Minister. The new policy contained three dimensions:

- Cultural identity: the right of all Australians, within carefully defined limits, to express and share their individual cultural heritage, including their language and religion;

- $\quad$ Social justice: the right of all Australians to equality of treatment and opportunity, and the removal of barriers of race, ethnicity, culture and religion, language, gender or place of birth; and 
- Economic efficiency: the need to maintain, develop and utilise effectively the skills and talents of all Australians, regardless of background (OMA, 1989).

The National Agenda, while recognizing the neo-conservative part of multiculturalism, that is, recognition of cultural difference also added a social democratic element of social justice. Further, it added a neo-liberal element of economic efficiency, highly reflective of the economic rationalism of the late 1980 and 1990s. This was called 'productive diversity' and advocated the benefits of diversity to assist in trade and business. Despite the introduction of managerial multiculturalism (Jayasuriya 1997), the National Agenda marked a shift away from an 'ethnic group' model towards a 'citizenship' model. As a public policy measure, it incorporated ethnic diversity as being central to contemporary Australian society. It recognised that the state had the duty to take measures to ensure equal opportunity and prevent marginalisation of minority groups. National identity was based on heterogeneity and cultural diversity was not seen as a threat to Australian nation building. Thus, the period 1987-1996 was marked by an institutionalisation of multiculturalism. All Commonwealth Government Departments were expected to report annually against 'access and equity' statements, or benchmarks. This new approach was facilitated by a number of government departments including the Office of Multicultural Affairs (OMA) in the Department of Prime Minister and Cabinet, the Department of Immigration and Ethnic Affairs and the Bureau of Immigration, Multicultural and Population Research. At the state level, the state governments followed suit and established state Ethnic Affairs Commissions or Departments.

\section{New racism and the politics of exclusion under the Howard government}

The election of the Howard government in 1996 led to a re-defining of the principles of multiculturalism. The New Agenda was introduced in 1999 and amended in 2003 and adopts the motto Unity in Diversity. Unlike the Hawke-Keating policy, The New Agenda is not couched in citizenship terms but expressed in terms of 'civic duties' and introduces the demand for mutual obligations and the responsibilities of citizens. This policy is also embedded in a form of 'new nationalism' that gives legitimacy to the Anglo-Celtic heritage of Australia as the basis of national unity and social 
cohesion. Howard was elected at a time when the One Nation Party was established as a 'neo-right wing party' with calls to redefine Australia in terms of its Anglo-Saxon roots and to negate its cultural diversity (Gabriel 1998, Hage 2003).

Under the Howard government, multiculturalism has only been tolerated and its formal status has been weakened. For example, after coming to power, the government terminated many of the institutions of Multiculturalism including the Office of Multicultural Affairs (OMA) and the Bureau of Immigration, Multicultural and Population Research (BIMPR). The Human Rights and Equal Opportunity Commission (HREOC), SBS television and the Aboriginal and Torres Strait Islander Commission (ATSIC) were impose with sever funding cutbacks (Manne: 2002). OMA was the government's official advisory body on multicultural affairs. The BIMPR conducted very significant research into the settlement needs of ethnic communities.

The Howard government's movement away from strengthening multiculturalism and cultural diversity along with its negative discourses on asylum seekers and the war on terror, has weakened the fabric of society, leading to the revival of 'new racisms': following the implementation of multiculturalism, the 'old racism' in which ethnic communities were viewed as inferior has been largely replaced by 'new racism' (also termed 'cultural racism'). With the advent of this form of racism, ethnic communities are differentiated as being a 'threat to the cultural integrity' of the Anglo Celtic host society (Dunn et.al: 2004). Questions as to who does/does not belong to Australian society, what/who is/is not Australian are integral aspects of the intolerance to some groups and the new racism in Australia (Dunn et.al: 2004). The answers to these questions have changed with time: Asians and Indigenous Australians have historically been identified as the other. Most recent examples include Arabs and Muslims (Dunn et.al: 2004). Essentially, the key element of 'old racism', the so called 'incompatibility' of different ethnic groups and their 'inability' to co-exist, remains as an integral aspect of 'new racism' (Corlett: 2002).

Over the last ten years, the climate for refugees, asylum seekers and immigrants has become more and more unwelcoming. Whilst Pauline Hanson was elected in the 1990s's on an anti-immigrant/refugee platform, calling for an end to all Asian immigration, the Howard government adopted her hard line policies into mainstream politics (Abraham: 2005). In pushing its harsh asylum and counter terrorism policies and its hard line stance on the war in Iraq, the Howard government has deliberately 
and persistently negatively portrayed Arabs and Muslims as the 'other' with the effect of demonising and dehumanising them (Poynting and Noble: 2004. Higgins \& O'Brien: 2005; Howie: 2005).

The discussion and debates around asylum seekers, terrorism and the war in Iraq have been interwoven with issues relating to Australian values and national identity and have ultimately reinforced particular discourses and types of patriotism. There has been a deliberate attempt to create a unique and homogenous national identity that attempts to unite some parts of the community while excluding others. The new forms of patriotism that have emerged are racialised and draw boundaries of inclusion and exclusion. Who is an Australian, what are Australian values, and what is 'un-Australian' have been re-defined resulting in the marginalisation, criminalisation and exclusion of the 'voiceless' 'other'.

\section{Commentary}

Although progressive at the time of its inception, essentially multiculturalism emphasised tolerance of ethnic groups on condition that the dominant Anglo culture ultimately prevailed (Teo: 2003). Following on from this, 'whiteness' has been the norm from which other cultures have been viewed as 'ethnic'. The consequence of this has been that 'whiteness' continued to dominate the cultural landscape in Australia and has never been adequately questioned (Teo: 2003). Accordingly, multiculturalism has not significantly succeeded in overcoming racism and prejudice in Australia and the concept of race has continued to remain as a key element of Australian national understanding (Stratton: 1998).These arguments are further complicated by the reality that multiculturalism is not enshrined in legislation and is only encapsulated in policy, making it easy to change. These weaknesses have been exploited in full by the Howard government.

The rhetoric of multiculturalism tends to suppress heterogeneity and constructs culture and ethnicity as particular labels. There is a constant tension between tolerance and the tolerated (ethnic groups). Thus, this process is one of 'Othering' where the ethnic communities are on the outside, appearing to create binary relationships between 'ethnic communities' and 'Australian society' as if the two are mutually exclusive. Although the policy stresses that multiculturalism is for all Australians, in practice the binary relationships hold. Multiculturalism is for 'ethnics' and it pigeonholes migrants as people who are permanently marginalised. The interpretation of the policies of multiculturalism leave the 'Anglo- 
Saxon or Celtic' Australians as not being considered as ethnic communities, although they have come to Australia from other lands. Thus, official multiculturalism is based on the hegemony of the AngloCeltic culture but makes this invisible through enabling of the creation and expression of ethnicity categories (Bhabha 1994, Vasta and Castles 1996).

The policies of multiculturalism, while employing'All-Australian' rhetoric have failed to reconcile key issues in the management of diversity: cultural pluralism or social cohesion; individual or group rights; ethnic or Australian identity. Thus, they have been laid open to criticism from both supporters and opponents. The social justice agenda of multiculturalism, as outlined above, failed to achieve outcomes for those most disadvantaged - both in distributional and relational terms. The project of Australian nation building requires affiliation and involvement between the state and ethnic communities. However, the state apparatus is considered as a homogenising entity that is structurally not capable of responding within a pluralistic framework. This creates further tension when ethnic communities try to negotiate difference within state structures and leads to calls for commitment, loyalty and allegiance to the nation state (Strattan 1998).

Multiculturalism as a nation-building tool continues to be seen as problematic in the public arena. The key arguments have been that multiculturalism undermines national identity, challenges core values, is a threat to social cohesion in Australia and that it is divisive. Central to these debates is the notion that a homogenous Australia exists and migrants do not fit in this framework, integrate or assimilate, introduce foreign practices, tend to 'stick together' in ghettoes and bring their overseas conflicts to Australia (Betts 1988, Blainey 1984 and 1995).

It has been argued that ethnicity is an instrument of population management and is intended to serve a political agenda which desires to obscure the fundamental systems of disadvantage, namely class and gender (Collins 1991, Jakobowicz Goodall 1994, Castles et al. 1988). These comments are made in the light that pluralism has not been able to adequately address fundamental issues in relation to the inequitable distribution of societal resources and the vesting power and privilege to some people. While this has raised the question whether ethnicity causes disadvantage, multicultural policies have not met the challenge of addressing disadvantage faced by many ethnic groups as a result of migration. 
Proponents of the Left have argued that class and gender are equally important in understanding inequality (Bottomley et.al.1991, Pettman 1992) while the critics from the Right have focused on human capital theory and the market demand for skills and qualifications (Stromback 1988).

Multiculturalism, as a policy, has been used to serve the post-war reconstruction needs of Australia. Although cultural and ethnic identity was allowed (or tolerated), it did not bring about changes in economic, political, legal or other structures of Australian society. It entrenched Anglo-Celtic norms as the basis of social formation and established the English language as the national language without debate or renegotiation (Jayasuriya 1997). It assumed that immigrants would integrate into the Australian society based on this relationship of dominance of one group over the others.

This lack of questioning of power relations of society resulted in a continued silence on racism and discrimination (Jayasuriya 1997). Although multiculturalism discusses social cohesion, this is couched more in terms of building a unified nation. There is no discussion of negative behaviour on part of the dominant group against the minorities in society. Often, racism is couched in soft language, equating it with (negative) community relations. This fails to address fundamental issues against discriminatory behaviour and action. Although there is legislation in place to address racism, Australia continues to be marked by prejudice, racism and intolerance. As Collins (1991, ii) states "The Australian and Canadian experience suggests that prejudice coexists with tolerance, as does racism with social harmony and multiculturalism with ethnic inequality". It is argued that state policies of multiculturalism are not concerned as much with fostering cultural difference as much as creating safe channels that contain difference (Stokes 1997). The project of Australian nation building requires affiliation between the state and ethnic communities although the state apparatus has not been adequate in responding within a pluralistic framework (Vasta \& Castles 1996).

The current climate for Multiculturalism is somewhat an ambiguous one. On the one hand there is bi-partisan support for 'Multicultural Australia' by the Government and the Opposition- at least at a rhetorical level. On the other hand, there are wavering Government and Opposition responses to key issues relating to multiculturalism that confront the nation such as the rights of asylum seekers and the policy of detention and the targeting of particular communities in the fight against the war on terror. For example the Prime Minister stated "I do think there is this particular fragment 
which is utterly antagonistic to our kind of society and that is a difficulty" and "I think some of the associated attitudes to women are a problem" (The Australian, 20/2/2006, p.1). The use of the words "our kind of society" is an interesting play on words. What is this society he is referring to? This kind of rhetoric finds resonance amongst some sections of Australian society. Similarly other terms are used such as 'core Australian values' However the interesting element of these debates is that there is not a definition anywhere to be found of what are core Australian values. The discussion of core Australian values leads to key questions what are the values, who is determining them and where are the public platforms for the decisions about core values. The earlier debates of multiculturalism in the 1970s did debate these issues and touched upon core values as being rule of law, democracy, use of the English language and rights of citizens as set out in law (Smolicz 1981). Some of these have been reflected in the various policies of multiculturalism. These have not been debated since the 1970s although we live in a changed political and social environment. Also the discussion of the core values of society is often confused with the processes that are established in society such as rule of law. The rule of law is not a value but a process of how a society will take actions and decisions. A wide range of values underlies the rule of law that needs explicit specification. Other challenges, flowing out of statements such as the above mentioned by the Prime Minister, relates to arguments about 'fitting in'. Australian settlement policies have progressed from the 'assimilationist' approaches of expecting immigrants to conform to dominant cultures. This is the very essence of multiculturalism - respect for identity and expression of cultural heritage, albeit within the rule of law. No one is challenging the notion that the rule of law should not apply. However, the expectation that people should fit into one kind of lifestyle and society is contrary to the aims of multicultural policies and can be described as a guised return to policies of assimilationism.

The last decade of the conservative government has slowly seen a decline in the systems that support people across the board from issues such as education to health. We see a greater deregulation and a shift towards privatization, including privatization of welfare. We witness incremental steps in de-stating where safety nets are diminished in small steps and a transfer of government responsibilities to both the private and the community sector (to the community sector at a reduced costs) (Everingham 2003). This has been accompanied by rhetoric around mutual obligation - not rights but responsibilities - the overall result being 
diminished focus on social justice, equity components in many policy areas, including multicultural policies.

\section{Conclusion}

Multiculturalism not only entails rights for minorities but also deeply concerns societal values and the nature of the society that Australia needs to build. If Australia is to move forward with its multicultural policies, then resort to policies based on economic rationalist and neoliberal agendas need to be replaced with a more inclusive multiculturalism which is based on human rights, citizenship and social justice.

\section{References}

Abraham, $Y$ On the beach: Why the recent riots in Australia should surprise no one, Boston Globe: 25 December 2005, www.boston.com/news/globe/ideas/articles/2005/12/25/on the beacch?mode=PF

Betts K. (1988) Ideology and Immigration: Australia 1976 to 1987, Melbourne University Press: Melbourne.

Bhabha H. (1994) The Location of Culture, Routledge: London.

Blainey G. (1984) All for Australia, Methuen Hayes: Sydney.

Blainey G. (1995) 'New Racism Threatens Harmony of Diverse Society,' The Weekend Australian, 8-9 $9^{\text {th }}$ April, p.33.

Bottomley G., de Lepervance M. \& Martin J. (1991) Intersexions: Gender, Class, Culture, Ethnicity, Allen and Unwin: Sydney.

Castles S., Kalantzis M., Cope B., Morrisey M. (1988) Mistaken Identity: Multiculturalism and the Demise of Nationalism in Australia, Pluto Press: Sydney.

Collins J. (1991) Migrant Hands in a Distant Land, 2nd ed, Pluto Press: Leichhardt. 
Corlett, D (2002) Asylum Seekers and the New Racism, Dissent, No. 8, AutumnWinter, pp. 46-47

Department of Immigration and Multicultural Affairs www.immi.gov.au/multicultural/australia.index accessed 10 March 2006.

Dunn, K, Forrest, J, Burnley; I McDonald, A "Constructing Racism in Australia" in Australian Journal of Social Issues, Volume 39, No. 4, November 2004, pp. 409-430

Everingham C. (2003) Social Justice and the Politics of Community, Ashgate Publishing, pp. 95-108.

Freeman, P. and Jupp, J. (1999) Nations of Immigrants. Australia, The United States and International Migration, Oxford Uni Press, Melbourne.

Gabriel J. (1998) Whitewash: Racialized Politics and the Media, Routledge: London.

Hage G. (2003) Against Paranoid Nationalism, Searching for Hope in a Shrinking Society, Polity Press: Annandale

Higgins. E \& O'Brien. N, 'Kid Glove Syndrome', The Weekend Australian, 28 January 2006, www.theaustralian.news.com.au/common/story_page/o,5744,217960005\%255E2 , accessed 7 March 2006

Hollinsworth,D (1999) Race and Racsim in Australia, second edition, Social Science Press, Sydney

Howie, $L$ 'The threat of Terrorism and Social Change' in Human Rights Defender, AHRC, University of NSW, Special Issue, 2005.

Jakubowicz A. \& Goodall H. (1994), Racism, Ethnicity and the Media, Allen and Unwin: St Leonards.

Jamrozik A., Boland C., Urquhart R. (1995) Social Change and Cultural Transformation in Australia, Cambridge University Press: New York. 
Jayasuriya, L., (1997) Immigration and Multiculturalism in Australia: Selected Essays by Laksiri Jayasuriya, School of Social Work and Social Administration: The University of Western Australia.

Jayasuriya L. (2003) 'Australian Multiculturalism: Past, Present and Future,' paper presented at Managing Diversity Conference, 1-3 October 2003, Melbourne.

Jupp J., McRobbie A., \& York B., (1991) Settlement Needs of Small, Newly Arrived Ethnic Groups, Australian Government Publishing Service: Canberra.

Larbalestier, J. (1999) What is this thing called White? Reflections on 'whiteness' and Multiculturalism" pp. 145-162 in Hage. G \& Couch. $R$ The Future of Australian Multiculturalism. Reflections on the Twentieth Anniversary of Jean Martin's The Migrant Presence, Research Institute for Humanities and Social Sciences, University of Sydney.

Manne, R (2001) The Barren Years: John Howard and Australian Political Culture, Text Publishing, Melbourne.

McMaster, D. (2001) Asylum Seekers: Australia's Response to Refugees, Melbourne University Press, Melbourne.

Office of Multicultural Affairs (OMA) (1989) National Agenda for a Multicultural Australia, Department of Prime Minister and Cabinet, AGPS: Canberra.

Pettman J., (1992) Living in the Margins: Racism, Sexism and Feminism in Australia, Allen \& Unwin: St Leonards.

Poynting. S \& Noble. G, Living with Racism. The experience and reporting by Arab and Muslim Australians of Discrimination, Abuse and Violence Since September 2001, Report to the Human Rights and Equal Opportunity Commission, 19 April 2004, www.hreoc.gov.au/racial_discrimination/isma/research/index.html , accessed 17 February 2006

Smolicz. J., (1981) 'Core Values and Cultural Identity,' Ethnic and Racial Studies, Vol 4, No 1., pp. 75-90. 
Stokes, G. (1997) The Politics of Identity in Australia, Cambridge University Press, Cambridge.

Stratton, J (1998) Race Daze, Australia in Identity Crisis, Pluto Press, Sylvania Waters.

Teo.H.M (2003) Multiculturalism and the Problem of Multicultural Histories: An Overview of Ethnic Historiography in Teo.H.M \& White. R (eds.) Cultural History in Australia, UNSW Press, Sydney.

Vasta E. \& Castles S. (1996) The Teeth are Smiling; the Persistence of Racism in Multicultural Australia, Allen and Unwin: St Leonards.

Zubryzcki J. (1982) Multiculturalism for All Australians, AGPS: Canberra. 